\title{
PROBLEM KONSTYTUCYJNOŚCI ART. 68 USTAWY O EMERYTURACH I RENTACH Z FUNDUSZU UBEZPIECZEŃ SPOŁECZNYCH W KONTEKŚCIE KONTYNUACJI NAUKI NA STUDIACH DOKTORANCKICH
}

\section{RENTA RODZINNA ORAZ CEL TEGO ŚWIADCZENIA}

Niniejszy artykuł dotyka dotychczas nie poruszanej w piśmiennictwie kwestii prawa do renty rodzinnej ${ }^{1}$ dla uczestników studiów doktoranckich w kontekście ustawowych granic przyznawania tego świadczenia oraz praktyki orzeczniczej. Ponadto w zestawieniu z innymi regulacjami publicznoprawnymi, ze szczególnym uwzględnieniem Konstytucji Rzeczypospolitej Polskiej z 2 kwietnia 1997 r. $^{2}$ i zawartych w niej zasad równości wobec prawa oraz prawa do pomocy socjalnej ze strony państwa. Z uwagi na zakresowy temat artykułu dalszej analizie badawczej zostaną poddane wyłącznie regulacje odnoszące się do dzieci osoby zmarłej, które są jednocześnie doktorantami.

Renta rodzinna to okresowe świadczenie pieniężne o łącznym i wtórnym charakterze ${ }^{3}$ wypłacane ze środków zgromadzonych na Funduszu Rentowym będącym wyodrębnioną częścią Funduszu Ubezpieczeń Społecznych. Jej podstawę prawna stanowi ustawa z 17 grudnia 1998 r. o emeryturach i rentach z Funduszu Ubezpieczeń Społecznych ${ }^{4}$. Zgodnie z art. 65 i 66 ww. ustawy upoważnionymi do poboru omawianego świadczenia sa ,uprawnieni członkowie rodziny" zmarłego, czyli osoby, które w chwili śmierci: a) miały ustalone prawo do emerytury lub renty z tytułu niezdolności do pracy, b) spełniały warunki wymagane do uzyskania jednego z ww. świadczeń, c) w chwili śmierci pobierały zasiłek przedemerytalny, świadczenie przedemerytalne lub nauczycielskie świadczenie kompensacyjne. Wspomnianymi wcześniej uprawnionymi

${ }^{1}$ Dalej również jako: r.r.

${ }^{2}$ Dz. U. Nr 78, poz. 483 ze zm. (dalej jako: Konstytucja).

${ }^{3}$ W doktrynie prawa zwraca się uwagę na problem skategoryzowania powyższego świadczenia. Wskazują na to m.in. M. Bartnicki, w: K. Antonów (red.), Emerytury i renty z FUS. Emerytury pomostowe. Okresowe emerytury kapitałowe. Komentarz, Warszawa 2014, s. 402-403; Ł. Prasołek, w: B. Gudowska, K. Ślebzak (red.), Emerytury i renty z Funduszu Ubezpieczeń Społecznych. Emerytury Pomostowe. Komentarz, Warszawa 2013, s. 206-207; A. Wypych-Żywiecka (red.), Leksykon prawa ubezpieczeń społecznych. 100 podstawowych pojęć, Warszawa 2009, s. 203-209. Kompleksowo problem ten opisała A. Wypych-Żywiecka, Renta rodzinna z Funduszu Ubezpieczeń Społecznych. Zagadnienia materialnoprawne, Gdańsk 2006, s. 162-179.

${ }^{4}$ T.jedn.: Dz. U. 2016, poz. 887 ze zm. (dalej jako: u.e.r.). 
członkami rodziny osoby zmarłej są: 1) dzieci własne, drugiego małżonka oraz dzieci przysposobione; 2) przyjęte na wychowanie i utrzymanie przed osiagnięciem pełnoletniości wnuki, rodzeństwo i inne dzieci5; 3) małżonek (wdowa i wdowiec); 4) rodzice (w tym macocha oraz ojczym). Osoby te muszą spełnić dodatkowo szczegółowe warunki określone w art. 68-71 u.e.r.

Cel świadczenia renty rodzinnej nie został wprost określony w u.e.r. W wypadku pierwszej i drugiej grupy świadczeniobiorców cel ten został jednak dekodowany na gruncie orzecznictwa sądowego. Sąd Najwyższy w wyroku z 11 kwietnia 1996 r. (II UR 4/96) ${ }^{6}$ stwierdził, że zasadniczym celem r.r. jest dostarczanie środków utrzymania tym dzieciom pracownika (rencisty), które $\mathrm{w}$ związku z kształceniem się $\mathrm{w}$ szkole nie wykonują pracy stanowiącej źródło utrzymania. Podkreślić należy, że choć powyższy wyrok w swojej materii dotyczył nieobowiązującej już ustawy z 14 grudnia 1982 r. o zaopatrzeniu emerytalnym pracowników i ich rodzin ${ }^{7}$, to nadal pozostaje on aktualny. Jednoznacznie wskazuje na to wyrok SN z 23 listopada 2011 r. (II UK 71/11), w którego uzasadnieniu Sąd uznał, że art. 39 ust. 1 pkt 2 ust. z 1982 r., jest odpowiednikiem art. 68 ust. 2 u.e.r. $\mathrm{Na}$ tej podstawie SN przez subsumcję orzeczeń wydanych pod reżimem poprzedniej ustawy potwierdził ich aktualność na gruncie (odpowiednich) obecnie obowiązujących przepisów. Stanowisko to zostało następnie powtórzone w wyroku SN z 17 października 2006 r. (II UK 73/06) ${ }^{9}$.

Z uwagi na fakt, że r.r. ma charakter okresowy ustawodawca wprowadził granice, których przekroczenie skutkuje wygaśnięciem prawa do pobierania omawianego świadczenia. Zgodnie z art. 68 ust. 1 u.e.r. prawo do r.r. (co do zasady) przysługuje do ukończenia przez dziecko zmarłego 16 roku życia. W przypadku gdy po ukończeniu 16 lat dziecko zmarłego (świadczeniobiorca) kontynuuje naukę ${ }^{10}$, prawo do poboru renty rodzinnej, przysługuje do czasu ukończenia tejże nauki, nie dłużej jednak niż do osiagnięcia 25 roku życia. Wyjątkiem od powyższej reguły - okresowości prawa do pobierania omawianego

${ }^{5} \mathrm{Z}$ wyłączeniem dzieci przyjętych na wychowanie i utrzymanie w ramach rodziny zastępczej lub rodzinnego domu dziecka.

${ }^{6}$ OSNP 1996, nr 20, poz. 311.

${ }^{7}$ Dz. U. Nr 40, poz. 267 ze zm. (dalej jako: ustawa z 1982 r.).

${ }^{8}$ Lex nr 1308099.

${ }^{9}$ OSNP 2007, nr 21-22, poz. 325.

${ }^{10} \mathrm{~W}$ dosłownym brzmieniu mowa jest o nauce w szkole. Określenie to pojawiło się również w ustawie z 1982 r., gdzie powodowało duże wątpliwości interpretacyjne, zob. S. Szymańska, Niektóre problemy na tle prawa dzieci uczacych się do renty rodzinnej, „Praca i Zabezpieczenie Społeczne" 1983, nr 7, s. 59-63. Obecnie należy rozumieć je jako naukę w szkołach podstawowych lub ponadpodstawowych, publicznych lub niepublicznych państwowych lub niepaństwowych szkołach wyższych, szkołach prowadzonych przez kościół katolicki, a ponadto pozaszkolne formy kształcenia, dokształcenia bądź doskonalenia zawodowego w tym kursy języków obcych prowadzone pod nazwą szkół lub ośrodków, przy czym muszą one trwać co najmniej 3 miesiące. Uprawnienie do omawianego świadczenia nie jest determinowane formą kształcenia, co również oznacza, że może nauka w formie szkolnej, pozaszkolnej, w systemie stacjonarnym, zaocznym, wieczorowym, a nawet korespondencyjnym. Zob. A Kobierska Informator Zaktadu Ubezpieczeń Społecznych. Renta rodzinna, Warszawa 2001, s. 9. Powyższy pogląd został w całości zaaprobowany w wyroku SN z 13 maja 2014 r. (I UK 414/13, OSNP 2015, nr 8, poz. 115), w którym SN rozszerzył powyższa definicję również o uczestników studiów doktoranckich oraz słuchaczy studiów podyplomowych. 
świadczenia - jest sytuacja, o której mowa w art. 68 ust. 1 pkt 3 u.e.r. Zgodnie z nim, gdy świadczeniobiorca w okresie do 16 roku życia lub gdy pobiera naukę po ukończeniu 16 roku życia, jednak nie dłużej niż do ukończenia 25 lat, stanie się całkowicie niezdolny do pracy oraz do samodzielnej egzystencji prawo do renty rodzinnej traci swój okresowy charakter, stając się uprawnieniem bezterminowym ${ }^{11}$.

Reasumując, za wyłączeniem sytuacji wyjątkowych w obecnym porządku prawnym, prawo do renty rodzinnej przysługuje od chwili powstania okoliczności uprawniających do jej poboru ${ }^{12}$, kończy się (wygasa) zaś z chwilą ukończenia studiów w szkole wyższej. Jednoznacznie wskazuje na to ust. 2 powyższego przepisu, umożliwiajacy warunkowe przedłużenie prawa do poboru renty rodzinnej w sytuacji, w której świadczeniobiorca ukończy 25 roku życia i będzie na ostatnim roku studiów w szkole wyższej ${ }^{13}$. W takiej to sytuacji prawo do poboru renty rodzinnej jest (warunkowo) przedłużane do zakończenia tegoż etapu kształcenia (ostatniego roku studiów) ${ }^{14}$.

\section{PRZYKŁADY JEDNORODNEGO TRAKTOWANIA STUDENTÓW I DOKTORANTÓW}

Ratio legis ustalenia cezury w uprawnieniu do r.r. na granicy ukończenia przez świadczeniobiorcę 25 roku życia miała na celu umożliwienie im nauki w szkole wyższej. Innymi słowy, omawiana granica została wprowadzona przez ustawodawcę z myśla o studentach, czyli - zgodnie z art. 2 ust. 1 pkt 18k ustawy z 27 lipca 2005 r. - Prawo o szkolnictwie wyższym ${ }^{15}$ - osobach kształcących się na studiach wyższych, do których z kolei zalicza się studia pierwszego stopnia, studia drugiego stopnia oraz jednolite studia magisterskie ${ }^{16}$.

11 Choć w u.e.r. nie zostało to określone, w omawianej sytuacji jest ono de facto dożywotnie. Z tego również względu należy stwierdzić, że świadczenie to jest wyłącznie względnie okresowe.

12 Zob. wyrok SN z 5 października 2006 r. (I UK 117/06) z glosą aprobującą I. Sierockiej, OSP 2008, nr 10, poz. 105.

${ }^{13}$ Warto dodać, że w praktyce orzeczniczej podkreśla się, iż kształcenie to musi mieć charakter rzeczywisty - świadczeniobiorca musi faktycznie pobierać tę naukę, por. wyrok SN z 6 listopada 2012 r. (III UK 153/11, Lex nr 1318422), wyjątkiem jest sytuacja tzw. urlopu dziekańskiego, zob. wyrok SN z 3 października 2000 r., II UKN 739/99, OSP 2003, nr 2, poz. 26 z glosą aprobująca H. Pławuckiej, oraz wyrok SN z 27 kwietnia 1982 r. II URN 74/82, OSNCP 1982, nr 12, poz. 204.

${ }_{14}$ Problem ustalenia granicy ostatniego roku studiów pojawił się już w ustawie z 1982 r., wówczas to SN przyjął, że student, który na przedostatnim roku studiów, w czerwcu, zdał wszystkie wymagane egzaminy i który ukończył 25 rok życia przed rozpoczęciem zajęć w nowym roku akademickim, zachowuje prawo do r.r. do zakończenia ostatniego roku studiów, zob. uchwała SN z 23 lutego 1989 r., III UZP 3/89, z glosą aprobującą T. Bińczyckiej-Majewskiej, OSP 1990, nr 5-6, poz. 246. Podobne stanowisko zajął SN w wyroku z 8 sierpnia 2007 r., II UK 15/07, stwierdzając, że ustalenie daty, w której dziecko pobierające r.r. było na ostatnim roku studiów, następuje na podstawie wpisu na ostatni rok studiów dokonany w oparciu o regulamin studiów obowiązujący na uczelni. Pogląd ten, inaczej niż uchwała z 1989 r., został jednak skrytykowany. Zob. wyrok SN z 8 sierpnia 2007 r., II UK 15/07, z glosą krytyczną A. Wypych-Żywieckiej, OSP 2009, nr 3, poz. 27.

15 T.jedn.: Dz. U. 2016, poz. 1842 ze zm. (dalej jako: p.s.w.).

${ }^{16}$ Art. 2 ust. 1 pkt 5 p.s.w. 
Bezsprzecznie wskazuje na to wspomniany wcześniej ust. 3 art. 68 u.e.r. Pogląd ten wyraził również SN w wyroku z 3 marca 2011 r. (II UK 303/10) ${ }^{17}$. W jego uzasadnieniu można przeczytać:

granica wiekowa 25 lat wiąże się z obiektywną i powszechną możliwością ukończenia przez dziecko studiów wyższych. Od osoby pobierającej rentę rodzinną należy oczekiwać w tej kwestii zachowania zwykłej staranności ${ }^{18}$.

Z tego również względu w tym miejscu pojawia się zasadniczy problem prawa do omawianego świadczenia w stosunku do osób, które bezpośrednio po ukończeniu studiów wyższych kontynuują naukę w ramach tzw. studiów doktoranckich. Studia te, określane na gruncie p.s.w. jako studia trzeciego stopnia (art. 2 ust. 1 pkt 10 p.s.w.), sa tego rodzaju stopniem (etapem) kształcenia, „na które sa przyjmowani kandydaci posiadający kwalifikacje drugiego stopnia” (art. 2 ust. 1 pkt 18 g p.s.w.) i które kończą się uzyskaniem kwalifikacji trzeciego stopnia (art. 2 ust. 1 pkt 18 h p.s.w.).

Samo uznanie doktoratu za kolejny etap kształcenia - jako studia trzeciego stopnia jest pokłosiem przyjęcia przez Rzeczpospolitą tzw. deklaracji bolońskiej, tj. dokumentu zawierającego zadania mające na celu ustandaryzowanie systemów szkolnictwa wyższego krajów europejskich ${ }^{19}$. W przypadku studiów doktoranckich najistotniejsze znaczenie miał tzw. komunikat berliński, będący efektem konferencji ministrów edukacji państw sygnatariuszy deklaracji bolońskiej (19 września 2003 r.). W komunikacie berlińskim po raz pierwszy pojawił się postulat „ustudiowania” ${ }^{20}$ doktoratu oraz włączenia go w tzw. proces boloński.

Biorąc zaś pod uwagę dotychczasowy polski system oświaty - zakładający rozpoczęcie nauki w szkole podstawowej w wieku 7 lat - osoby nieprzerwanie kontynuujacce naukę, przyjęte na studia doktoranckie są w wieku od 23 lat (w przypadku osób urodzonych po dacie 1 października) do 25 lat (w przypadku absolwentów czteroletnich techników zawodowych, urodzonych przed data 1 października). Powoduje to powstanie problemu dostosowania regulacji art. 68 ust. 1 oraz 2 u.e.r. do unormowań polskiego systemu szkolnictwa wyższego.

Jak wskazuje dotychczasowa praktyka orzecznicza, Sądy uznaja, że studia doktoranckie należy traktować per analogiam do studiów wyższych. Dobitnie świadczy o tym wyrok Sądu Apelacyjnego w Rzeszowie z 13 czerwca 2013 r. (III AUa 257/13) ${ }^{21}$, w którego uzasadnieniu Sąd stwierdził, że:

Choć studia doktoranckie służą pogłębieniu wiedzy zdobytej na jednolitych studiach magisterskich lub im odpowiadającym, i uzyskaniu wyższych kwalifikacji, to w aktualnej sytuacji panującej na rynku pracy, uznać należy, że ich ukończenie może determinować w ogóle podjęcie pracy w zawodzie. Tymczasem celem renty rodzinnej ma być zabezpieczenie finansowe

17 OSNP 2012, nr 7-8, poz. 98.

18 Ibidem.

19 Zob. M. Pyter, A. Balicki (red.), Leksykon prawa oświatowego i prawa o szkolnictwie wyższym. 100 podstawowych pojęć, Warszawa 2014, s. 247-251. Szeroko na temat deklaracji bolońskiej, w: J. Górniewicz (red.), Wymiar społeczny procesu bolońskiego, Olsztyn 2005.

20 Por. przyp. 25.

21 Lex nr 1327603. 
możliwości kształcenia się sieroty bądź półsieroty celem zdobycia kwalifikacji umożliwiajacych podjęcie pracy, w zamyśle pracy zgodnej z tymi kwalifikacjami. Zgodne z tym celem zasadne jest zatem przyjęcie, że również doktorantce, która ukończyła dwudziesty piąty rok życia będąc na ostatnim roku studiów doktoranckich (studiów w szkole wyższej), prawo do renty rodzinnej przedłuża się do zakończenia tego roku studiów ${ }^{22}$.

Powyższy pogląd koresponduje ze stanowiskiem SN zaprezentowanym w wyroku z 17 października 2006 r. (II UK 73/06) ${ }^{23}$, w którym uznał, że studia doktoranckie prowadzone przez Polską Akademię Nauk należy traktować jako naukę w szkole w rozumieniu u.e.r. ${ }^{24}$

Skutkiem tak pojmowanego kształcenia na studiach doktoranckich jest powstanie istotnego deliktu prawnego - niedostosowania przez ustawodawcę granicy prawa do poboru r.r. dla uczestników tychże studiów. Problem ten jest dodatkowo uwypuklony, kiedy weźmie się pod uwagę zarówno pozostałe przepisy u.e.r., inne regulacje polskiego systemu ubezpieczeń społecznych, jak i pozostałe unormowania publicznoprawne.

Zgodnie z art. 7 pkt 9 oraz 9a u.e.r. okresem nieskładkowym jest zarówno okres „nauki w szkole wyższej na jednym kierunku, pod warunkiem ukończenia tej nauki, w wymiarze określonym w programie studiów", jak i okres „studiów doktoranckich i aspirantury naukowej ${ }^{25} \mathrm{w}$ wymiarze określonym

${ }^{22}$ W tym również miejscu należy dodać, że w wyroku SN z 13 stycznia 2006 r., I UK 155/05, OSNP 2006, nr 23-24, poz. 368 oraz z 22 stycznia 2008 r., I UK 207/07, OSNP 2009, nr 5-6, poz. 74, SN stwierdził, że omawiana regulacja nie ma zastosowania w przypadku słuchaczy studiów podyplomowych. Pogląd ten pozostaje wysoce kontrowersyjny. Jeżeli bowiem przyjąć, że jedyną przesłanką warunkującą zastosowanie powyższego przepisu jest miejsce kształcenia, którym musi być szkoła wyższa (bądź instytucja jej równoważna, jak np. PAN), to studia podyplomowe spełniaja ten warunek. Zgodnie z art. 2 ust. 1 pkt 11 p.s.w. są one tego rodzaju formą kształcenia, „na która są przyjmowani kandydaci posiadający kwalifikacje co najmniej pierwszego stopnia, prowadzona w uczelni, instytucie naukowym PAN, instytucie badawczym lub Centrum Medycznym Kształcenia Podyplomowego, kończące się uzyskaniem kwalifikacji podyplomowych”. Analogiczny pogląd prezentuje R. Sadlik, który w glosie krytycznej do wyroku z 22 stycznia 2008 r. podkreślił, że art. 68 ust. 2 u.e.r. przez sformułowanie „studiów w szkole wyższej”, a nie „studiów wyższych” nie odsyła do ustawy o szkolnictwie wyższym, z tego również powodu, w jego ocenie, bez znaczenia pozostaje odrębność tego kształcenia; zob. idem, Glosa do wyroku Sadu Najwyższego z 22 stycznia 2008 r. - renta rodzinna dla studenta na ostatnim roku studiów podyplomowych, „Praca i Zabezpieczenie Społeczne” 2011, nr 4, s. 38-40. Zob. również D. Noszczak, Renta rodzinna dla osób pobierajacych naukę, „Służba Pracownicza” 2011, nr 6, s. 13-14, oraz M. Kwiatkowska, Renta rodzinna-odpowiedzi na pytania, „Przegląd Ubezpieczeń Społecznych i Zdrowotnych” 2002, nr 11, s. 29-30.

23 Zob. przyp. 10.

${ }^{24}$ Warto również wspomnieć, o wyroku SN z 6 września 2000 r., II UKN 699/99, wraz z glosa aprobującą M. Skapskiego, OSP 2001, nr 4, poz. 58, który był pierwszym orzeczeniem de lege lata nie tylko zrównującym doktorantów ze studentami w prawie do r.r.

${ }_{25}$ Aspirantura naukowa - istniejąca w Polsce w latach 1951-1958 forma kształcenia, służąca uzyskaniu stopnia naukowego, zorganizowana na zasadach studiów wyższych i adresowana do kadr naukowych i naukowo-pedagogicznych. Aspirantura naukowa była regulowana przez rozporządzenie Rady Ministrów z 26 kwietnia 1952 r. w sprawie organizacji aspirantury naukowej (Dz. U. Nr 24, poz. 163). Jej wdrożenie do polskiego systemu szkolnictwa wyższego było przejawem wdrażania sowieckich rozwiązań ustrojowoprawnych (tzw. wzorców), co miało związek z ówczesnym procesem stalinizacji prawa. Nie zmienia to jednak faktu, że z uwagi na to, że model aspirantury naukowej realizowany był na zasadach bardzo zbliżonych do systemu studiów wyższych, paradoksalnie był on więc quasi-protoplastą obecnie obowiązujących rozwiązań prawnych. 
w decyzji o ich utworzeniu". Analogiczne uregulowania występują na gruncie ustawy z 27 czerwca 2003 r. o rencie socjalnej ${ }^{26}$, gdzie - w myśl art. 4 ust. 1 pkt 2 i 3 - prawo do ubiegania się o rentę socjalna przysługuje osobie pełnoletniej całkowicie niezdolnej do pracy z powodu naruszenia sprawności organizmu, które powstało „w trakcie w trakcie nauki w szkole lub w szkole wyższej - przed ukończeniem 25. roku życia” bądź „w trakcie studiów doktoranckich lub aspirantury naukowej”. Tym samym także w tym przypadku zrównano w uprawnieniach studentów oraz doktorantów.

Ujednolicenie praw i obowiązḱw studentów oraz doktorantów (z drobnymi różnicami wynikającymi ze specyfiki tychże rodzajów kształcenia) ma miejsce również na gruncie innych przepisów. Przepisy p.s.w., na gruncie których występuje szereg odwołań w zakresie praw i obowiązków studenta, mających odpowiednie zastosowanie $\mathrm{w}$ stosunku do doktorantów ${ }^{27}$, nie są tego jedynym przykładem. Również w ustawie z 17 lipca 1998 r. o pożyczkach i kredytach studenckich ${ }^{28} \mathrm{w}$ art. 1 ust. 1 expressis verbis określono, że prawo do otrzymania pożyczek i kredytów mają zarówno studenci, jak i doktoranci. Zwraca uwagę bardzo precyzyjnie określenie regulacji umożliwiających przyznanie pożyczki/ kredytu studenckiego doktorantom. Zgodnie z art. 7 ust. 2a powyższej ustawy maksymalnym okresem, na jaki przyznawane sa pożyczki/kredyty studenckie, jest okres czterech lat. Nie jest on przypadkowy, gdyż do 31 października 2014 r. przepisy prawa powszechnie obowiązującego ściśle regulowały minimalny i maksymalny czas trwania tychże studiów ${ }^{29}$.

Kolejnym przykładem przepisów jednakowo traktujacych w prawach i obowiązkach studentów oraz doktorantów sa przepisy ustawy z 20 czerwca 1992 r. o uprawnieniach do ulgowych przejazdów środkami publicznego transportu zbiorowego ${ }^{30}$, gdzie w art. 4 ust. $4 \mathrm{a}$ i $4 \mathrm{~b}$ ustawodawca wprowadził ulgę w tej samej wysokość (51\%) za przejazdy środkami publicznego transportu zbiorowego kolejowego w pociagach osobowych, pospiesznych i ekspresowych, na podstawie biletów jednorazowych. Jest to istotne, gdyż zgodnie z art. 4 ust. 4 pkt 2 ww. ustawy dzieci i młodzież w okresie od rozpoczęcia odbywania obowiąkowego rocznego przygotowania przedszkolnego do ukończenia gimnazjum, szkoły ponadpodstawowej lub ponadgimnazjalnej (publicznej lub niepublicznej o uprawnieniach szkoły publicznej), korzystają z innej zniżki (37\%). Innymi słowy, także w tym przypadku ustawodawca nie tylko zrównał w uprawnieniach studentów oraz doktorantów, ale i - mając na uwadze, że studia doktoranckie rozpoczynają się po zakończeniu studiów (jednolitych

26 T.jedn.: Dz. U. 2013, poz. 982 ze zm.

27 Przykładem czego jest art. 199 ust. 1 pkt 1 p.s.w. upoważniający doktorantów do otrzymywania stypendium socjalnego, co do którego - zgodnie z art. 199 ust. 4 p.s.w. - mają odpowiednie zastosowanie regulacje dotyczące studentów. Dodatkowo środki przeznaczane na wypłatę tego stypendium pochodzą z tego samego źródła, co jasno stwierdza art. 96 ust. 1 pkt 2 w związku z art. 94 ust. 1 pkt 1 i 4 p.s.w.

28 T.j.: Dz. U. 2017, poz. 357.

${ }^{29}$ Obecne regulacje - rozporządzenie Ministra Nauki i Szkolnictwa Wyższego z 9 sierpnia 2017 r. w sprawie studiów doktoranckich i stypendiów doktoranckich (Dz. U. poz. 1696) - nie wprowadzaja jednak maksymalnego okresu trwania studiów doktoranckich.

${ }^{30}$ T.jedn.: Dz. U. 2012, poz. 1138 ze zm. 
magisterskich lub drugiego stopnia), a więc osoby w nich uczestniczące będa $\mathrm{w}$ wieku starszym od przeciętnego studenta (ulga wynikająca z art. 4 ust. 4a powyższej ustawy, przysługuje wyłącznie do ukończenia 26 roku życia) - przyznał prawo do ulgowych przejazdów doktorantom aż do ukończenia przez nich 35 roku życia.

\section{PROBLEM KONSTYTUCYJNOŚCI ART. 68 U.E.R.}

Zasadniczym pozostaje jednak pytanie, jak wobec powyższego należy traktować nieproporcjonalne określenie granicy prawa do r.r. w stosunku do omawianej grupy społecznej (doktorantów). Na pierwszy rzut oka regulacja art. 68 ust. 1 u.e.r. wydaje się wpisywać w wyrażoną w art. 32 Konstytucji zasadę równości wobec prawa. Faktycznie jednak tak nie jest. Należy bowiem podkreślić, że równość wobec prawa jest pojęciem niejednoznacznym i nie może być traktowane jako synonim „identyczności”. Równość oznacza jednakowość jednej lub kilku cech uznanych za istotne, podczas gdy identyczność - jednakowość wszystkich cech określonych podmiotów ${ }^{31}$. W odniesieniu do prawa równość może być rozumiana dwojako, tj. zarówno jako równość stosowania prawa oraz jako równość w prawie. Pierwsza sytuacja oznacza stosowanie norm prawnych w oderwaniu od jednostkowych cech adresatów tychże norm, które to w danej sytuacji sa jednocześnie irrelewantne ${ }^{32}$. Druga zaś sytuacja łączy się z materialnym charakterem prawa, a konkretniej z założeniem, że normy obowiąującego prawa sa sprawiedliwe i słuszne, czyli nie zawieraja postanowień dyskryminujacych bądź faworyzujacych pojedyncze podmioty ${ }^{33}$. Wpisujące się w to zróżnicowanie w prawa i obowiązkach wymaga zawsze oceny kryterium dyferencji, które z kolei musi mieć nie tylko istotny charakter, ale również wykazywać się cechą proporcjonalności. Ponadto pozostawać również w bezpośrednim związku z innymi wartościami bądź (konstytucyjnymi) zasadami uzasadniajacymi odmienne traktowanie podmiotów podobnych ${ }^{34}$. Tym samym badając konstytucyjność aktu normatywnego, należy ustalić biorąc pod uwagę cel i treść badanej regulacji - czy istnieje wspólna cecha istotna uzasadniająca równe traktowanie określonych podmiotów prawa. Jeżeli norma prawna traktuje odmiennie podmioty prawa posiadające wspólna cechę istotna, to wprowadza ona odstępstwo od zasady równości. Jest ono dopuszczalne, jeżeli zostały spełnione trzy warunki: 1) wprowadzone przez prawodawcę różnicowania muszą być racjonalnie uzasadnione, biorąc pod uwagę cele i treść przepisów, w których zawarta jest kontrolowana norma; 2) waga interesu, któremu ma służyć różnicowanie podmiotów podobnych, musi pozostawać w odpowiednie proporcji do wagi interesów, które zostaną naruszone

\footnotetext{
${ }^{31}$ W. Sadurski, Równość wobec prawa, „Państwo i Prawo” 33, 1978, z. 8-9, s. 51-52.

${ }^{32}$ Ibidem, s. 55.

${ }^{33}$ Ibidem, s. 59.

${ }^{34}$ I. Sierpowska, Pomoc społeczna jako administracja świadczaca. Studium administracyjnoprawne, Warszawa 2012, s. 137.
} 
w wyniku różnego traktowania podmiotów podobnych; 3) regulacja prawna musi znajdować podstawę w wartościach, zasadach lub normach konstytucyjnych, uzasadniających odmienne traktowanie podmiotów podobnych ${ }^{35}$.

Powyższy pogląd został w pełni aprobowany przez Trybunał Konstytucyjny, który w orzeczeniu z 9 marca 1988 r. (U 7/87) stwierdził, że:

konstytucyjna zasada równości wobec prawa (równości w prawie) [...] polega na tym, że wszystkie podmioty prawa (adresaci norm prawnych) charakteryzujące się daną cechą istotna (relewantna) w równym stopniu mają być traktowani równo. A więc według jednakowej miary, bez żadnych różnicowań zarówno dyskryminujących jak i faworyzujących. [...] równość oznacza także akceptację różnego traktowania przez prawo różnych podmiotów (adresatów norm prawnych), bo równe traktowanie przez prawo tych samych podmiotów pod pewnym względem oznacza z reguły różne traktowanie tych samych podmiotów pod innym względem. [...] W ocenie Trybunału Konstytucyjnego różne traktowanie przez prawo określonych grup (klas) podmiotów powinno być uzasadnione w tym sensie, że musi być oparte na uznanych kryteriach oceny klasyfikacji różnicującej podmioty prawa. Równość wobec prawa to także zasadność wybrania tego, a nie innego kryterium zróżnicowania podmiotów (adresatów) prawa. Oznacza ono uznanie tej, a nie innej cechy, za istotna, a tym samym uzasadniona w regulowanej dziedzinie (materii). [...] podstawowym kryterium oceny klasyfikacji podmiotów (adresatów norm) dokonywanych w prawie jest to, że klasyfikacje te obok zgodności z innymi, pragmatycznymi kryteriami, muszą być sprawiedliwe społecznie $^{36}$.

Podkreślić należy, że powyższe orzeczenie było następnie szeroko cytowane w późniejszym orzecznictwie Trybunału ${ }^{37}$ oraz sądów $^{38}$.

Mając na uwadze fakt, iż w powyżej cytowanym orzeczeniu TK odwołał się do - obecnie wyrażonej w art. 2 Konstytucji - zasady sprawiedliwości społecznej, ważne jest, aby przytoczyć tutaj jego wyrok z 23 października $2007 \mathrm{r}$. $(\mathrm{P} 28 / 07)^{39}$. W uzasadnieniu TK wywiódł zawarte w powyższym przepisie określone wzorce postępowania:

Trybunał konsekwentnie zajmuje stanowisko, że z wyrażonej w art. 2 Konstytucji zasady państwa prawnego wynika nakaz przestrzegania przez ustawodawcę zasad poprawnej legislacji. Nakaz ten jest funkcjonalnie związany z zasadami pewności i bezpieczeństwa prawnego oraz ochrony zaufania do państwa i stanowionego przez nie prawa. [...] Poprawność legislacyjna to także stanowienie przepisów prawa w sposób logiczny i konsekwentny, z poszanowaniem zasad ogólnosystemowych oraz z zachowaniem należytych aksjologicznych standardów. Niezgodne $\mathrm{z}$ tą zasadą będzie więc wprowadzanie do obrotu prawnego przepisów (nawet gdy celowość takich przepisów mogłaby się wydawać słuszna), które tworzą regulacje prawne niekonsekwentne i niedające się wytłumaczyć w zgodzie z innymi przepisami prawa. Celo-

35 J. Oniszczuk, Równość - najpierwsza z zasad i orzecznictwo Trybunału Konstytucyjnego, Warszawa 2004, s. 86. Por. wyrok TK z 21 września 1999 r., K 6/98, OTK ZU 1999, nr 6, poz. 117.

${ }^{36}$ OTK 1988, poz. 1.

${ }_{37}$ Zob. m.in. wyrok z 16 grudnia 1997 r. (K 8/97, OTK ZU 1997, nr 5-6, poz. 70), w którym TK expressis verbis stwierdził, że „[...] mimo pewnej różnicy w sformułowaniu zasady równości w art. 32 konstytucji w stosunku do dawnego art. 67 ust. 2 przepisów konstytucyjnych dotychczasowe orzecznictwo dotyczące zasady równości zachowuje aktualność w nowym porządku konstytucyjnym”, bądź wyrok TK z 21 września 1999 r., K 6/98, OTK ZU 1999, nr 6, poz. 117.

38 Zob. m.in. wyrok NSA z 1 lutego 2008 r., I OSK 608/07, Lex nr 486362.

39 OTK-A 2007, nr 9, poz. 106. 
wość i ewentualna zasadność wprowadzania w życie danych regulacji prawnych nie może być wytłumaczeniem dla tworzenia prawa w sposób chaotyczny i przypadkowy. Dowolność i przypadkowość wprowadzanych w życie przepisów prawnych jest zatem złamaniem zasady poprawnej legislacji ${ }^{40}$.

Przenosząc powyższe rozważania na grunt prawa do renty rodzinnej dla doktorantów, należy stwierdzić, że specyfika kształcenia na studiach trzeciego stopnia nie tylko nie odbiega od specyfiki kształcenia na studiach wyższych (pierwszego i drugiego stopnia), ale wręcz wymaga znacznie większego zaangażowania od ich uczestników. Artykuł 197 p.s.w. wśród obowiązków doktoranta na pierwszym miejscu (ust. 1) wymienia postępowanie zgodne z treścią ślubowania i regulaminem studiów doktoranckich. In fine odsyła także do odpowiedniego stosowania art. 189 ust. 2 p.s.w., a więc rozszerza obowiązki doktorantów również o: uczestnictwo w zajęciach dydaktycznych i organizacyjnych; składanie egzaminów, odbywanie praktyk i spełnianie innych wymogów przewidzianych planem studiów oraz przestrzeganie postanowień wewnętrznych przepisów uczelnianych. To jednak w ust. 2 i 3 (art. 197 p.s.w.) rozszerzono obowiązki doktoranta również o te wynikające ze specyfiki tego etapu kształcenia, czyli o prowadzenie badań naukowych i składanie sprawozdań z ich przebiegu. To z jednej strony odróżnia status uczestników studiów doktoranckich od studentów, z drugiej zaś upodabnia do nauczycieli akademickich, gdyż doktoranci uczelni maja ponadto obowiązek odbywania praktyk zawodowych polegających na osobistym prowadzeniu zajęć dydaktycznych albo uczestnictwie w zajęciach prowadzonych przez inną osobę ${ }^{41}$. Podsumowujac, niewątpliwie kontynuacja nauki na studiach trzeciego stopnia (doktoranckich) wiąże się z nie tylko z faktyczną niemożliwością podjęcia pracy zarobkowej, ale również stoi na przeszkodzie finansowemu usamodzielnieniu się świadczeniobiorcy.

Z tego również względu, biorąc pod uwagę całokształt przepisów prawnych (systemu ubezpieczeń społecznych, oświaty i szkolnictwa wyższego oraz konstytucyjnego katalogu praw i wolności), należy uznać, że brak na gruncie u.e.r. unormowań prawnych umożliwiajacych pobór r.r. przez osoby kontynuujace naukę na studiach trzeciego stopnia jest niedostosowaniem tych regulacji do obecnego systemu szkolnictwa wyższego. Charakteryzuje się ono nie tylko przypadkowością (czym nie czyni zadość zasadom prawidłowej legislacji), lecz również skutkuje powstaniem sytuacji nieuzasadnionego odmienne traktowania - dyskryminacji - omawianej grupy osób, co jest naruszeniem art. 32 Konstytucji ${ }^{42}$.

W tym miejscu warto przytoczyć wyrok SN z 5 maja 2010 r. (I PK 201/09) ${ }^{43}$, w którym określona została sytuacja dyskryminacji, o której mowa w art. 32 Konstytucji. Według SN ze wspomnianego przepisu wynika zarówno nakaz

40 Ibidem.

${ }^{41}$ D. Dudek, w: M. Pyter (red.), Prawo o szkolnictwie wyższym. Komentarz, Warszawa 2012, s. 969 .

${ }^{42}$ Por. T. Liszcz, Ubezpieczenia społeczne $w$ orzecznictwie Trybunału Konstytucyjnego, w: M. Żukowski (red.), Systemy ubezpieczeń społecznych - między solidaryzmem a indywidualizmem, Warszawa-Lublin 2014, s. 39-42.

43 OSNP 2011, nr 20-21, poz. 270. 
równego traktowania przez władze publiczne, jak i zakaz stosowania dyskryminacji w życiu politycznym, społecznym i gospodarczym. Sąd zastrzegł, że dyskryminacji nie mogą usprawiedliwiać żadne przepisy i żadne przyczyny, podkreślił jednak, że nie zawsze odmienne potraktowanie stanowić będzie o dyskryminacji. Ocena zróżnicowania sytuacji podmiotów musi za każdym razem wynikać z jego uzasadnionego charakteru. W ocenie SN różnicowanie jest uzasadnione, jeśli pozostaje w związku bezpośrednim z celem przepisów, waga zaś interesu, dla którego zróżnicowanie jest wprowadzone, pozostaje w proporcji do interesów naruszanych, a zróżnicowanie nie uwłacza w sposób zasadniczy innym wartościom.

Zaprezentowany wcześniej cel omawianego świadczenia, jakim jest zapewnienie niezbędnych środków utrzymania dziecku zmarłego, wpisuje się w konstytucyjne wolności - prawa ekonomiczne, socjalne i kulturalne. Tym samym analiza zgodności art. 68 ust. 1 u.e.r. z ustawą zasadniczą niewątpliwie nie ograniczy się tylko do art. 32 Konstytucji, m.in. z uwagi na fakt, że największą grupę świadczeniobiorców renty rodzinnej stanowią dzieci osoby zmarłej ergo członkowie rodzin niepełnych, w naturalny sposób wiąże go z art. 71 ust. 1 Konstytucji ${ }^{44}$.

Najnowsze orzecznictwo TK aprobuje pogląd, iż art. 71 ust. 1 Konstytucji jest dostatecznie skonkretyzowany, by stanowić podstawę wzorca kontroli konstytucyjnej ${ }^{45}$. Zastrzegł przy tym, że - z uwagi na programowy charakter pierwszego zdania wspomnianego przepisu - konstytucyjnym wzorcem kontroli może być wyłącznie zdanie drugie tego ustępu ${ }^{46}$. W wyroku z 10 marca 2015 r. (P 38/12) ${ }^{47}$ Trybunał stwierdził m.in., że:

artykuł 71 ust. 1 zdanie drugie Konstytucji ma bardziej skonkretyzowana, odpowiadająca strukturze prawa podmiotowego publicznego, treść: rodzina (znajdująca się w trudnej sytuacji materialnej i społecznej) ma prawo do działania państwa, polegającego na udzielaniu lub zapewnieniu udzielenia (szczególnej) pomocy. Zakres swobody ustawodawcy jest w tym wypadku węższy, bowiem Konstytucja precyzuje cechy podmiotu uprawnionego, która jest rodzina znajdująca się w trudnej sytuacji materialnej i społecznej, zwłaszcza wielodzietna i niepełna, oraz definiuje treść działania Państwa na rzecz rodziny, która stanowi „,szczególna pomoc”. Jak stwierdził Trybunał w wyroku z 9 lipca 2012 r. (P 59/11, OTK ZU 2012, nr 7/A, poz. 76), określenie to należy rozumieć w sposób tożsamy na gruncie wszystkich powołanych przepisów konstytucyjnych. Wskazuje ono na „konieczność podejmowania takich działań władz publicznych, które wykraczać będa poza normalny standard ochrony wolności i praw. Chodzi tu zatem o działania przewyższające ów zwykły poziom ochrony gwarantowanej konstytucyjnie. Posłużenie się terminem „szczególny” odczytywać należy jako skierowany

${ }^{44}$ Choć prawo do zabezpieczenia społecznego in genere czerpie z art. 67 Konstytucji, to jednak (z uwagi na jego konstrukcję) nie można go wprost odnieść do r.r. Wynika to z niesamodzielnego rodzaju ryzyka ubezpieczeniowego (por. Ł. Prasołek, w: Emerytury..., s. 506), jak również i faktu, że zawarte w ust. 1 ujęcie enumeratywne zamyka jego oddziaływanie wyłącznie do sytuacji w nim wymienionych (A. Miruć, Konstytucyjne podstawy prawa do pomocy społecznej $w$ Polsce, „Administracja, Teoria, Dydaktyka, Praktyka" 2010, nr 1, s. 88; M. Zielnicki Prawo do zabezpieczenia społecznego, „Gdańskie Studia Prawnicze” 13, 2005, s. 580), a ust. 2 rozszerza to prawo wyłącznie na wypadek sytuacji bezrobocia z jednoczesnym brakiem innych środków utrzymania (W. Skrzydło, Konstytucja Rzeczypospolitej Polskiej. Komentarz, Warszawa 2013, s. 81-82).

${ }_{45}$ Zob. wyrok TK z 10 marca 2015 r., P 38/12, OTK-A 2015, nr 3, poz. 29.

${ }^{46}$ Ibidem.

${ }^{47}$ Ibidem. 
w stosunku do władzy publicznej nakaz bardziej intensywnego traktowania pewnej grupy podmiotów z uwagi na sytuację faktyczna, w jakiej się znajdują" (wyrok z 9 lipca 2012 r., sygn. P 59/11), to jest wykraczającego poza zakres „zwykłego” uwzględniania potrzeb tych podmiotów (zob. wyroki: z 15 listopada 2005 r., P 3/05 i z 8 maja 2001 r., P 15/00). „Szczególna pomoc" ma niewątpliwie wymiar konkretny i możliwe jest ustalenie, czy ustawodawca wyposażył organy władzy publicznej w środki prawne umożliwiające jej świadczenie. [...] Państwo jest zatem konstytucyjnie obowiązane do udzielenia lub zapewnienia udzielania szczególnej pomocy tym rodzinom, a zakres, formy, wysokość i sposób jej udzielania określa prawodawca, z uwzględnieniem, że pomoc ta jest pomocą szczególną, a zatem wyróżniającą się wśród innych form pomocy udzielanej przez państwo i mająca wyjątkowe znaczenie dla rodzin jej potrzebujących. [...] Obowiązek ten musi być natomiast rozumiany jako nakaz urzeczywistnienia w ustawach treści prawa konstytucyjnego w taki sposób, aby z jednej strony uwzględniało istniejące potrzeby, z drugiej możliwości ich zaspokojenia ${ }^{48}$.

Powołany w powyższym wyroku termin „trudnej sytuacji społecznej i materialnej" został rozwinięty w wyroku TK z 18 listopada 2014 r. (SK 7/11) ${ }^{49}$, gdzie zdefiniowano go jako sytuację, w której warunki bytowe nie pozwalają rodzinie na „wypełnianie funkcji, jakie państwo wiaże z rodzina” ${ }^{50}$. Z kolei trudną sytuację społeczną należy utożsamiać z „nienaturalnym, zachwianym stanem osobowym rodziny oraz zakłóceniami w jej funkcjonowaniu z racji niewypełnienia lub nienależytego wypełniania ról społecznych przez członków rodziny" ${ }^{1}$. Trybunał dodał, że niezależnie od tego, że często występuja one równocześnie, obowiązek szczególnej pomocy państwa aktualizuje się już przy wystapieniu jednej z nich. Bezsporne jest, że śmierć jednego z rodziców świadczeniobiorcy wiąże się nie tylko z zachwianiem stanu osobowego danej rodziny, ale również z zakłóceniem w jej funkcjonowaniu. W cytowanym wyżej wyroku TK zwrócił również uwagę na niezwykle istotny aspekt:

Konstytucja gwarantuje rodzinom wielodzietnym i niepełnym, które spełniają warunek trudnej sytuacji materialnej i społecznej (por. art. 71 ust. 1 zdanie drugie Konstytucji), więcej niż zwykłą pomoc. Pomoc, która ma mieć charakter szczególny, oznacza konieczność preferencyjnego traktowania osób należących do danej kategorii podmiotów, wyprzedzającego konstytucyjną ochronę o „zwykłej” intensywności, i musi pozwolić każdej takiej rodzinie na w miarę normalne funkcjonowanie w społeczeństwie. [...] W tym sensie ochrona przewidziana w art. 71 ust. 1 zdaniu drugim Konstytucji oznaczać ma wyraźne podwyższenie tego standardu ochrony i pomocy, który ustrojodawca przyznaje wszystkim rodzicom i rodzinom (por. art. 18 Konstytucji). [...] Celem regulacji konstytucyjnych odnoszących się do statusu rodziny jest nałożenie na państwo, a zwłaszcza na ustawodawcę, obowiązku podejmowania takich działań, które umacniają więzi między osobami tworzącymi rodzinę, a zwłaszcza więzi istniejące między rodzicami i dziećmi oraz między małżonkami (por. wyrok z 12 kwietnia 2011 r., sygn. SK $62 / 08)^{52}$.

Z tego również względów usprawiedliwione jest postawienie tezy, że brak przepisów, które wprost umożliwią odpowiednie stosowanie art. 68 ust. 1 u.e.r. w stosunku do uczestników studiów doktoranckich, prowadzi nie tylko do dyskryminacji tej grupy osób, ale również do dyskryminacji rodzin, z których pochodzą.

\footnotetext{
48 Ibidem.

${ }^{49}$ OTK-A 2014, nr 10, poz. 112.

50 Ibidem.

51 Ibidem.

52 Ibidem.
} 
Teza ta wymaga precyzyjnego uzasadnienia. Sygnalizowana dyskryminacja rodzin doktorantów, wynika z faktu, iż uczestnicy studiów doktoranckich - członkowie rodzin niepełnych, a więc rodzin konstytucyjnie podlegających szczególnej ochronie i wsparciu ze strony państwa - wobec niedostosowania regulacji art. 68 ust. 1 u.e.r., mimo obiektywnego faktu kontynuacji nauki na studiach trzeciego stopnia (studiach doktoranckich), w trakcie ich trwania zostają w nagły (i całkowicie nieuzasadniony) sposób pozbawieni omawianego świadczenia. To z kolei w świetle przytoczonego wyżej orzecznictwa w znaczący sposób narusza obowiązek z art. 71 ust. 1 Konstytucji, jako że utrata prawa do renty rodzinnej każdorazowo będzie negatywnie oddziaływać na sytuację materialną doktorantów oraz ich rodzin.

Utrata omawianego dochodu, a w konsekwencji pogorszenie sytuacji materialnej doktorantów (oraz ich rodzin), w skrajnych wypadkach (np. sytuacji, w których r.r. jest podstawowym źródłem utrzymania) może prowadzić do porzucenia przez nich podjętego kształcenia. Tym samym utrata renty rodzinnej (pomimo kontynuacji nauki w ramach kolejnego etapu kształcenia) prowadzi do naruszenia art. 70 ust. 1 in principio oraz ust. 4 zd. pierwsze Konstytucji. Odebranie ww. grupie prawa do świadczeń zapewniajacych utrzymanie nie może bowiem uniemożliwić im kontynuację tego kształcenia.

\section{WNIOSKI DE LEGE FERENDA}

Uznanie art. 68 u.e.r. w zakresie, w jakim odmawia on prawa do świadczenia r.r. doktorantom po ukończeniu przez nich 25 roku życia, za niezgodny z Konstytucją nierozerwalnie wiąże się z ustaleniem dodatkowej granicy wiekowej, której przekroczenie skutkować będzie wygaśnięciem prawa do świadczenia. Wydaje się, że najwłaściwsze byłoby ustalenie tejże granicy na poziomie ukończenia 29 roku życia, czyli wydłużenie prawa do omawianego świadczenia o okres czterech lat. Uzasadnione jest to nie tylko wspomnianymi wcześniej przepisami z ustawy o pożyczkach i kredytach studenckich, ale również przepisami p.s.w. Zgodnie z art. 198 ust. 3 p.s.w. czteroletni okres studiów doktoranckich jest zaliczany do okresu pracy, od którego zależą uprawnienia pracownicze. Tym samym również słuszne pozostaje przyjęcie tezy, że - biorąc pod uwagę postanowienia Konstytucji oraz całość przepisów z zakresu systemu ubezpieczeń społecznych - ewentualna nowelizacja art. 68 u.e.r., której celem byłoby dostosowanie prawa do poboru r.r. również o czas nauki na studiach doktoranckich, powinna umożliwiać (w stosunku do doktorantów) odpowiednie stosowanie ust. 1 i 2 ww. przepisu, jednak nie dłużej niż do osiagnięcia przez świadczeniobiorcę 29 roku życia.

mgr Jakub Mrożek

Uniwersytet Wroctawski

jakub.mrozek@uwr.edu.pl 


\section{THE CONSTITUTIONALITY OF ARTICLE 68 OF THE ACT ON PENSIONS AND DISABILITY PENSIONS PAID FROM THE SOCIAL SECURITY FUND IN THE CONTEXT OF CONTINUED EDUCATION OF DOCTORAL STUDIES}

\section{Sum mary}

The article discusses the non-adjustment of the statutory limit relating to doctoral students, which sets out the right to a survivor's pension. First some general information on the benefits, with particular emphasis on the periodic nature of the benefit, is presented on the basis of selected decisions of the Supreme Court. This is followed by some examples of statutory regulations that equalise as well as differentiate the rights and obligations of doctoral students with those of other students. These findings are subsequently compared with the existing constitutional norms. A special emphasis has been placed on the principle of equality before the law and the right to social assistance from the State in this particular case. References have been made to the doctrine and the previous judicial decisions of the Constitutional Tribunal. In the final summary, some legislative amendments are proposed. 
